\title{
Territorialize Comprehensive Local Risk Management and Information Systems: Co-building Knowledge in the Field of Environmental Health
}

\author{
Maria del Carmen Rojas ${ }^{1}$, Ana Colombres ${ }^{2}$, Silvina Hidalgo $^{3}$, Oscar Lopez ${ }^{4}$, Daniel Machado ${ }^{4}$, \\ Viviana Mendoza ${ }^{5}$, Patricia Montero ${ }^{5}$, Analia Ocampo ${ }^{2}$ \\ ${ }^{1}$ Line of Research in Risk, Habitat and Health, Institute of Geohistorical Research, National Council of Research and Techniques-National \\ University of the Northeast, Resistencia, Argentina \\ ${ }^{2}$ Provincial Institute of Agricultural Education No. 217, Ministry of Education, Government of the Province of Córdoba, Villa del Totoral, \\ Córdoba, Argentina \\ ${ }^{3}$ Secretary of Health, Municipality of Villa del Totoral, Córdoba, Argentina \\ ${ }^{4}$ Higher Teacher Training College, Ministry of Education, Government of the Province of Córdoba, Villa del Totoral, Córdoba, Argentina \\ ${ }^{5}$ Provincial Institute of Technical and Secondary Education No. 74, Ministry of Education, Government of the Province of Córdoba Villa del \\ Totoral, Córdoba, Argentina
}

\section{Email address:}

dramariarojas@gmail.com (M. del C. Rojas),acolombres@gmail.com (A. Colombres), silvina.hidalgo@hotmail.com (S. Hidalgo), oscar9lopez@yahoo.com.ar (O. Lopez), danymachado963@gmail.com (D. Machado), vividancer15@gmail.com (V. Mendoza), patricia_montero_bga@hotmail.com (P. Montero), analiao@hotmail.com (A. Ocampo)

\section{To cite this article:}

Maria del Carmen Rojas, Ana Colombres, Silvina Hidalgo, Oscar Lopez, Daniel Machado, Viviana Mendoza, Patricia Montero, Analia Ocampo. Territorialize Comprehensive Local Risk Management and Information Systems: Co-building Knowledge in the Field of Environmental Health. Journal of Health and Environmental Research. Special Issue: Health and the Environment as a Resource for the Reduction of Social Inequalities in Argentina. Vol. 7, No. 1, 2021, pp. 39-48. doi: 10.11648/j.jher.20210701.18

Received: January 4, 2021; Accepted: February 20, 2021; Published: March 9, 2021

\begin{abstract}
At present, the act of thinking appears as idle and is displaced by the instrumental. Comprehensive local risk management (CLRM) and information systems (IS) in the field of environmental health (EH) are analyzed ignoring the actor's conception and the time from which they start. Common practice does not respect the ontological character that we recognize as artisanal and based on movements of social re-association and re-assembly. Because of this it is necessary to catch up with the innovations of the actors, in order to know and learn about the collective existence from their own point of view, without imposing any order, limiting diversity, teaching what they are or adding reflexivity to their practice. The purpose of this article is to challenge CLRM and IS as a technical answer without questions, versus a CLRM and IS as a territory, that is, as a space with questions based on institutions, procedures and concepts capable of bringing together and re-relating the social. For this purpose, we will analyze the science that moves in the dimension of philosophy and recover the passion that represents the question; the territory as a space of the singular and site of acting, where the relational and the symbolic are expressed crossed by capitals and fields that exceed the epistemological simplicity; equity and equality to reduce long-term risk; the moments of the processual logic of an SI in the reference framework: data, information, knowledge, communication for action (DIKCA); cognitive justice; the processes of co-building knowledge essentially constituted by the word and conversations that trigger processes. We affirm that environmental health is a key tool of social practice. It corresponds to all this vast set of practices and knowledge that a society sets in place to know its health and environment, in order to transform it. Therefore, the proposal is to cease understanding CLRM and SI as rational products, and to come to understand them as a human product and, therefore, made by humans who construct language a central feature of their existence. We believe that change is necessary, that new, or not so new problems cannot be solved with outdated ideas. However, acquiring and developing renewed ideas or concepts can create the false illusion that everything is easy, but it is not. The challenge is daunting, as much as the need is inescapable.
\end{abstract}


Keywords: Comprehensive Local Risk Management, Information Systems, Territory, Social Re-assembly

\section{Introduction}

The words "social" and "nature" used to hide two completely different projects, which go through both illassembled assemblies: one that seeks to trace relationships between unexpected entities and the other that seeks to keep those relationships in a whole where it is possible to live, to some extent. The mistake is not in trying to do two things at once - every science is a political project - the mistake is to interrupt the first thing because of the urgency of the second [1, p. 361].

In this sense, the structure of this work is made on the basis of the following questions: Why do CLRM and SI in the field of environmental health tend to be expressed as programs and not as territories?; Are programs the best response from the State to the needs of social groups, in terms of expanding rights and reducing inequalities?; Is the knowledge of social scientists sufficient to address the complexity of environmental health, or is it necessary to unlearn what we have learned by assembling and reassembling with communities and local governments (C/GL)?; Is it just a political conflict, or is there also an ontological, epistemological and praxiological conflict?

The purpose is to discuss CLRM and SI from a theory that leaves aside deconstruction as a goal to achieve, or even to overcome, by checking without limiting in advance the shape, size, heterogeneity and combination of associations [1]. From there, it is intended to understand the territory from the knowledge and conceptions of the world put at stake by the different actors based on the territory-history and society axis [2].

In this way, we seek to question the ideological project represented by the programs on CLRM and SI by analyzing their scientific basis as antagonistic to any emancipation project [3]. We intend to look for questions and not repeat answers, so we turn to different concepts with the intention of re-thinking environmental health.

\section{The Question in Science and Philosophy}

Breilh [4] says that Saramago [5] presents in his "Essay on Blindness" the metaphor of a world affected by an epidemic that spreads erasing the ability to see, and that renders useless all the material wealth and goods of culture generated by humanity. The aforementioned author emphasizes: "We do not go blind... we're blind. Blind people who see, blind people looking without seeing...". Too often we make the mistake of separating scientific work from knowledge from those social and ideological conflicts, as if technological and cultural advances (which have made the arts grow and sophisticate) and science are not intimately linked to the same historical mechanisms and relationships of social life.
That's why a CLRM and an SI are much more than a set of linear and formal relationships between variables. It is much more than simply manipulating and dissecting stories and other personal texts disconnected from the broader social relationships in which these stories were built. This makes it necessary to open up science by ventilating the field, opening doors to new epistemological and cultural ingredients that have been consolidated in CLRM and SI based on a new concept of what is a science, as a thinking that "bears fruits", as Milton Santos would describe [6].

However, as Heidegger [7] states, "science does not think", because it does not move in the dimension of philosophy and, although it depends on it, forgets to think and sacrifices the passion that represents the question and so is dominated by the instrumental. Hence, to think is to try to escape the totalizing answers that deny that polysemy is the element in which thought must move to be rigorous.

On the other hand, Bachelard [8] highlights "the laziness of philosophy" and points to the little space that philosophy of science occupies in it. In this sense it is worth returning to Castoriadis [9] who argues that it is necessary to "know what is thought and think about what is done", in order to think from a founding practice, since the foundation has no effect of transformation; and founding is not synonymous with informing, in the same way that being a player is different from being a commentaror of a game. For this reason, it is necessary to differentiate between discourses, practices and impact of practices so as not to go the wrong way. The question is central to thought, so we must give up "laboratory answers." Asking, thinking and doing in the field of environmental health are the axes of reflection on CLRM and SI.

\section{CLRM and SI: Programs as Answers or Territories as Questions}

The Welfare State, in the twentieth century, concerned with three overlapping elements to control poverty and exclusion: target populations, rules and benefits, and skilled workers. All this required the identification of target populations; its statistical, legal and administrative constitution; the creation of rights and assignments and the formation of a body of workers in the social field that manages the system [10]. This strategy lost legitimacy since it has been demonstrated that knowing is not synonymous with understanding, and that for more knowledge over populations is developed, it is not always sufficient to reach the understanding of personal or collective trajectories. The overabundance of statistical information with increasingly sophisticated methods and techniques cannot prevent the establishment of heterogeneous societies marked by inequalities [10]. The focus was put on economic growth, and not on a social issue. The proposals were that social 
issues would be resolved after the expansion of economic development. This was a fallacy, as the accumulation processes were not synonymous with distribution. In his research, Thomas Piketty [11] showed that, in the last two centuries, the countries with the most economic development were the ones that widened inequalities within their societies. Economic development made a big mistake: it reduced the social to an administrative approach to things and underestimated people's governance [12]. The problems were conceived as reproduction and growth, which objectified the social [13]. Progress was made in rules and plans from the central levels to organize a future understood as predictable. The emphasis was put on the development of techniques and tools. There was no need to think, and this hope deposited in the instrumental led Freud himself to describe modern man as a god with prosthetics [14].

CLRM and IS were nourished by the epistemological matrix of modernity which understands that nature must be controlled and that man must take possession of that kingdom. Reason explains reality and is the only way to produce truths [15]. There is no room for uncertainty: knowing the order that governs CLRM and IS will allow you to master risk, because it will submit to nature and its history. In opposition, Boaventura Santos points out that modern science reduces complexity by conceiving that, in order to know, it is necessary to divide and classify, and then establish relationships [16]. This way of understanding science lays the foundation for the belief in the infallibility of knowledge, the solidity of discourse, and scientific truth, in which man is reduced to consciousness, and ideology replaces mythology [17]. Santos describes this instrumental rationality [16] as indolent in resisting changing routines and transforming hegemonic interests into true knowledge that university students often repeat as universal truths, without recognizing that, frequently, they only represent European truth. The latter shows the colonization effect of this thinking, and that this method of working is the principle of authority, based on it being affirmed in texts considered as true.

The falsehood of these issues is shown in the persistence in Latin America of so-called neglected or forgotten diseases (tuberculosis, malaria, syphilis, etc.), housing deficit, aggravation of environmental issues, added up to significant percentages of population without water, sewers, as well as overcrowding, among others, despite international declarations claiming $100 \%$ coverage, since the middle of the last century. These are some of the examples that indicate the permanence of problems despite the multiplicity of existing programs on CLRM and IS in the field of environmental health. This situation expresses that, beyond the technique for solving these problems, there are at stake political-economic and ideological-cultural dimensions that constitute them as complex, exceeding the simplification that instrumental reason makes of them [18].

To transcend scholasticism, the solution to the above problems should cease to try adapting to what is written without contextualization. Reality expresses "error" (in relation with "established truths") and so, contradicts the texts. This situation needs to be reversed, so that the problems of CLRM and IS should provoke the texts, that is, instead of problematizing the problems, the texts [19] are problematic and the "universal truth" is set aside in the benefit of situated know-how [20, 21]. This requires working on the basis of questions, not answers of which questions are unknown, i.e. not only establish a hierarchy in scientific truth, but also in the social importance of the application of knowledge [22]. We have taken a long time to apprehend that disciplines do not always coincide with problems and can only cover some of the complexity [23]. However, we still deny that the world of experience is greater than the world of knowledge [3], which highlights the urgency of another ontology, epistemology and praxeology that lead to the consideration of CLRM and IS as territories.

\section{Ontology, Epistemology and Praxeology in CLRM and IS}

Modernity installed the idea that in the relationship between science, technique and society, science corresponded to the themes of nature, while politics was dealing with the themes of society [24]. This relationship presents challenges, because new problems (new parental structures, genetics, among others) have broken the boundaries between science and politics and are presented as hybrid objects [24] that mix the dimensions of nature and society and challenge practices, both politically and scientifically.

We must be careful here not to confuse this formulation with another that bears a strong resemblance to it, but which would lead us to a completely different project. Raising a political issue often means revealing behind a given state of things, the presence of until-then-hidden forces. But then you run the risk of falling into the same trap of giving social explanations that I criticized earlier and end up doing the exact opposite of what I want to mean by politics. If you use the same old repertoire of social ties already assembled to "explain" the new associations, even if you seem to be talking about politics, you don't speak politically: what you're doing is simply extending one more step the same repertoire of already standardized forces. One may feel the pleasure of providing a "powerful explanation", but that is precisely the problem: one participates in the expansion of power, but not the re-composition of its content.

..."You have to be sober with power", that is, abstain the most you can from using the notion of power for doubts that the shot will come out of the butt and hit the explanations instead of reaching the pointed target. There should be no powerful explanations without controls and balances.

... Tracking the iron bonds of necessity is not enough to explore what is possible. Whenever we accept a detox of the powerful explanations...

... being politically motivated now begins to take on a more specific meaning: we look for ways to record the novelty of partnerships and explore how to assemble them in a satisfactory way [1, p. 362-363]. 
From the above comes our idea of recognizing CLRM and IS as hybrid and complex objects in different dimensions, orders of movement and contradictions between ends of that movement. We trace as dimensions its being (ontological dimension), its conceptualization (epistemological dimension) and its form of practice (praxeological dimension). To paraphrase Breilh [13] we adopted a brief outline to ask ourselves about possible entries to understand CLRM and IS.

Ontological dimension (the being of CLRM and IS)

Domain: nature/society

Space: macro and micro dimension; categories that break down these general-particular dimensions of CLRM and IS, and singular-individual CLRM and IS in the EH field.

Movement character: reproduction (social environmental determiners -SED- of the EH field from more general spaces) and generation (processes that trigger SED from more particular spaces).

Hierarchy of movement/connection: subsuntion of the particular in general and of the general in particular, and of the generation in reproduction and reproduction in the generation.

Identity: in the most general spaces, communality between processes and in the most particular spaces, diversity between processes.

System: CLRM and IS open and irregular until closed and regular.

Basic contradiction: between protective processes in dialectical opposition to deteriorating processes in CLRM and IS.

Epistemological dimension (ideas about CLRM and IS)

Construction of CLRM and SI: as an object, concept and practice.

Forms of construction: in processes of knowledge cobuilding.

Praxis dimension (actions in CLRM and IS)

Sense and space of action: they can be promotional (when acting to expand and refine protective processes -PP- in all dimensions) or for prevention (when acting to avoid and counteract destructive processes-DP- in all dimensions).

So, we understand that CLRM and IS are complex objects, without the absence of simplicity, multidimensionality, unity, and concatenation. That is, they unrestrictedly emphasize the micro diverse and complex and recover the opposite movements of the macro, communality and the simple.

We interpret CLRM and IS to be shaped by the social reproduction and generation of SED and general and particular movement spaces using notions as a subsuntion and others that allow to synthesize and approximate the generality of society, the particularity of social groups and the uniqueness of individuals and their daily life; the perspective of different cultures in the epistemological and the expansion and improvement of protective processes, which prevents and counteracts destructive processes in the courses of action.

In other words, we must be clear that the dimensions mentioned are inseparable because they are deeply concatenated and form a system of relationships that, in order to be worked from an emancipating perspective, require to be placed in a practice of concrete transformation and to rely on a critical theory.

In the words of Granda [25], critical theory must interrogate environmental health such as history, projects, struggles, dreams, work, art and genius, whose management is also art, as creative action, not repetitive nor structured, and which tends to trigger collective processes [26]. Mintzberg and Motta point out that the possibility of having directorates with management capabilities occurs to the extent that the organization resembles an orchestra in which each performs his instrument virtuously, and all perform a score [27, 28]. However, unlike a concert, in which musicians rehearse for long hours to perform a succession of works that have a guided order, management does not know what to perform, and music scores are interspersed, that are not closely related to each other, such as, for example, classical works structured and in which instrumentalists do not have much scope for action; more contemporary works, in which musicians must adapt to more complex sonorities, continuous changes of times and tempos, to the simultaneous execution of different rhythms - polyrhythms-; to the disappearance of the compass as a conducting parameter, which requires a more active and attentive individual interpretation and, in turn, greater listening and understanding of the whole [26]. Therefore, the risk in CLRM needs more understanding and that it is built as a more undisciplined concept. This requires the promotion of environmental health prevention and promotion practices based on actors' processes using concepts such as vulnerability, because it makes it possible to consider the political senses of risk management, i.e., its origins and political consequences. The notion of vulnerability promotes the production of synthesis mediating knowledge, because it brings its conceptions closer to the apprehension of SED and the effectiveness in the management of PP and DP. As a result, vulnerability is a comprehensive script of behavioral, social and political-institutional dimensions.

Adopting the perspective of vulnerability has implications in various orders. As a way of knowing, it highlights the need for synthetic and interpretative/comprehensive procedures, of a trans disciplinary nature. As a resource for management, the notion of vulnerability reinforces the importance of radical politicization of this practice, as it will always refer to relational, valorative and world vision aspects, in defining what to observe/what to do. It also assumes the everprocedural, never-finalistic nature of this practice, since, in each new situation achieved, new horizons of interests, conceptions and values will enter the stage [29, p. 339].

In this sense, the approach to the processual logic of IS proposes to discuss its production and implementation processes. That is, what characterizes these stages and what is the relationship between them? An IS that supports CLRM should articulate the following elements: data, information, knowledge, communication and action (DIKCA); all of them oriented to an inclusive society. We understand all of these 
components as a set that constitutes a logic of processes formed in two subgroups, one related to production and one related to the application with unclear limits. The first component, linked to data and information; and the second, to knowledge and communication for action [30, p. 2700].

... as DIKCA logic progresses, the increasing complexity of terms is observed. Some of them have an important polysemy that encompasses a set of vague and contradictory definitions.

... It is not a question of indicating a new recipe that makes IS "work", but of alerting the incorporation of elements such as communication and action that are essential, since IS exists in organizations, and these should not be understood only from a rational or normative logic. We understand IS as open, complex systems, and in this way, the DIKCA proposal is understood as processual, where all the explicit elements are relevant and presented simultaneously or overlapping in reality.

... La integración de DIKCA en el proceso de trabajo es la forma de construir el camino, que según palabras de Moraes [31], nos lleve "da prática fragmentada ao exercício de la cidadania"...

One of the inequalities present in our society is that of access to information and knowledge.

In this regard, we refer to the concept of Castoriadis elucidation [32] and, taking up what was expressed in previous paragraphs, to "think about what is done and know what is thought". The construction, and reconstruction, of an IS is a dialectical process ("suppression, preservation, overcoming") in DIKCA process logic. Its epigenesis should not be overlooked, i.e., that each new stadium is built from previous stages. The risk of considering it as something given and without history would lead to relapse in immediacy [32].

We therefore agree that it is wrong to conceptualize CLRM and IS separately from the practical field, for the richness of the movement that is the fundamental dynamics of knowledge, is lost [13].

In short, we agree that CLRM is an approach to problems linked to internal and external demands and conflicts in the style of Russian dolls, Babuskas," which is always contained inside another. From there, most of the time in management, problems are not solved, but exchanged. In other words, there are always problems in management, if there were no problems, there would be no management [33].

Finally, we celebrate CLRM and IS as a hermeneutic and relational process, as a network of conversations based on a form of organization that is culture and which, in IberoAmerican countries, the latter is based on the most important narrative of that language, El Quixote de la Mancha. Flores [34] states: Quixote is not in the past, it is in the present and it is that tendency that We Hispanics have to fight air castle, to put the honor ahead and the wisdom of Sancho Panza. We understand, following Flores [34], that organizations are networks of conversations in which management acts predominate, i.e. petitions, and acts of commitments. That is why the relationship between conversations-communicationorganization-culture constitutes a virtuous circle.

\section{CLRM and SI as Territories Based on Questions}

Santos claims that modern science produces knowledge and ignorance. Scientist is made a specialized ignorant; and the common citizen, a widespread ignorant [35]. Thus, CLRM and IS as programs reproduce while territoriality is reduced to social participation, health workers or health and environmental promoters. Programmatic logic returns as revealed truths ancestral knowledge that was taken away by science from the communities themselves, for example, cooperatives of labor. That is why CLRM and IS do not need plans and programs but citizenship (the scientist, educators, social workers and communities in union with the Local Management that develops bonds based on care considering the craftsmanship of the task permeated by the chaos with which the social and relational processes mediated by the symbolic are presented [36-39]. This epistemic configuration causes much discomfort and no less suffering, because what is not understood is suffered. To install new practices you must remain true to the sentence of Paulo Freire which says that where the feet step on, the head thinks [40].

Difficulties in understanding the territorial and moving in a relational dynamic, in scenarios of increasing complexities and/or chaos, it induces the mastery of a centripetal logic that reproduces more than it produces, and leads scientists, educators, social workers and communities in union with local governments to try to entrench themselves in their institutions as a form of defense against that "external" that makes them uncomfortable and unstructured, and that is increasingly understood, since problems are more complex and more distant to their episteme.

The territory shows that the epidermis is not the limit of the individual and that if we go beyond the skin of each subject it can be transcended to think in terms of interaction and social play, and discover social vulnerabilities and the logics of power (macro and micro), as well as the power that underlies the territory [41, p. 159].

Questions mark the path of thought, and the possibility of asking them relates to the richness of the epidemic and theoretical framework. Facing the unintended, and accepting the collapse of certainties, will allow you to ask questions and avoid naturalization, complaint and/or anecdote. Therefore, it should not be feared to abandon the known that is not useful to venture into the unknown, on a journey without certainties of success. It is necessary to bet and be true to betting, to register for a logic of the event in which the objectives are not predicted in the future, but are recognized by looking back and identifying what is constructed, which generally is located away from what is thought/imagined, especially in its trajectory.

CLRM and IS as territory seek to prioritize the question as the beginning of thought, in order to produce encounters and events. The purpose is to retrieve and develop a practice that in its future builds spaces of freedom, reduces social inequalities, develops citizenship and builds new institutional ties in the territories. 
We recover the territory, not from a romantic conception, but we recognize, as Milton Santos points out [41, p. 160], that it can be home or jail for the subject, so it must be worked in an integral and diachronic way, seeking to account for the technical demand as long as it is situated, while still taking into account the ideological-cultural and economicpolitical components that constitute each problem. The territory is a human construction, unfinished, in permanent movement and transformation [38, p. 44].

\section{Dialogue in the Processes of Knowledge Co-building}

In order to be closer to human actions, roles in collective co-building of CLRM and IS knowledge must be democratized and balanced. That is why it is important to advance small and particularized stories devoid of pre-found categories, products of intellectuality, and to carry on at a very slow speed that lets you see the subjectivity and cognition of all actors [1]. It is necessary to recognize that any discursive construction, whether descriptive, prescriptive, inquisitive, expressive or reflective, is always a moment of dialogue that is ongoing. There is no language produced by a single author, since it is always produced between actors, even virtually.

Language-mediated understanding/interpretation of CLRM and IS is achieved by participating in a dialogue. Every dialogue is led by a story line that joins one speech with another, and where each speech gains meaning. The meaning is not given a priori and is not the property of any of its participants, but is woven as the dialogue takes place. As a result, we get closer to the sense of dialogue the longer it takes place and the more we participate in it. For this reason, when we seek dialogue, we perceive and appropriate the uniqueness of each of us in the face of what unifies: our horizons as humans.

Gadamer [42] refers to the "fusion of horizons" as the fundamental moment of hermeneutics. The self and the other are not the same, we are unique beings, but we can only live in common, and we need to live in common, because there is a linguistic sharing, at different levels, that create our community experiences and expand our reality beyond our restricted spatial and temporal experience. We communicate, socializing ourselves, by breaking these barriers, by expanding them, by melting horizons with each other. That is why, increasing our proximity to the human is actively exploring this fusion of horizons and raising to a richer level the mutual knowledge of those who interact through language.

In this sense, the fusion of horizons is a hermeneutic element of double importance. It is, first of all, a procedure, a movement of active participation in a dialogue, as noted above. And, at the same time, it is also an indication of truth achieved through understanding. That is, the more we perceive ourselves in contact with each other, not necessarily agreeing, but effectively understanding something, the closer we are to the truth of that encounter. As a result, we understand that: (a) practical truth is an ever ongoing experience, limitless and open to resignification; b) when we actively seek to connect with another horizon (another person, another culture, another era, another place, another experience), seeking to respond to something that we visualize from our own horizon, is when we can understand the self and the other; c) hermeneutic knowledge occurs through, and when there is, the fusion of horizons; the hermeneutic experience will be all the more significant, the more actively we share and promote this fusion of horizons [43, p. 167].

We try to seek in an ancient principle of hermeneutics this which includes us and upset us in our horizons and leads us to rebuild the comprehensive totalities through which simultaneously, we place the world and place ourselves and the other in that world, according to the aplicatio or application concept proposed by Gadamer [42]. The application is, in short, the practical impulse, the interest in the realization of the Good Life in relation to CLRM and IS, which produces a need to situate us through some experience, interpret its meanings to know what to do.

Care must be taken not to confuse the application, to which hermeneutics refers, with purpose, in the instrumental perspective. The only thing about means-purpose relationships is what marks the methodical pursuit of a given goal, as a determined technical success. That's not what it's all about here. We are in the area of practical achievement: there are no predetermined results or formal guarantees of relationships between process and outcome. The interest rate raised here arises exactly from this opening of outcomes and processes, because it necessarily includes alterity, the participation of the other (the familiarly unknown, the recognized distinct). Here, both processes and outcomes will be the result of the encounter, of the fusion of horizons [43, p. 168].

The proposed reasoning is intended to avoid reproducing relationships of domination and/or silencing over actors in knowledge production processes.

In this sense, taking up Latour [1], we maintain that we must not limit beforehand any actor who populates the social world. Hence, we assert that it is possible to feed back with controversies, learn to relativize and stabilize them, which is an indispensable preparation to venture into a CLRM and an IS that promotes Good Life.

Finally, and to paraphrase Latour [1], we can say that knowledge-construction processes should be expressed as a travel guide and not as a method or methodology. That travel guide is given through a completely banal and exotic terrain, and suggests where to travel and what is worth seeing there. It cannot be confused with the territory to which it simply overlaps. To do this we have to collectively apprehend the process to slow down with each step.

... have all the difficulties involved in traveling been recognized? Hasn't the traveller cheated by subreptitiously transporting himself in an existing social order? In the meantime, my advice is to carry as little as possible, don't 
forget to pay your ticket and be ready to withstand delays [1, p. 45].

\section{It Happened in Villa Del Totoral, Córdoba, Argentina}

There we find the authors of this writing...

In 2012 we signed an agreement between the National Council of Scientific and Technical Research (CONICET), the Córdoba Regional Faculty of the National Technological University (UTN-FRC) and the Municipality of Villa del Totoral, Argentina. The Convention is a non-exclusive License for free use of the Diagnostic Methodology and Associated Software (DMHRH and RHH version 2.1, Lic. 647178/25/3/2008). The Diagnostic Methodology of Housing Risk for Health (DMHRH) and Risk, Housing and Health (RHH) software is an IS in a DIKCA process to interpret household risk in homes for environmental health. It is based on a holistic and complex conception from the perspective of global vulnerability, focused on social vulnerability, sustainable development as a process, environmental collective health and artificial intelligence [44].

The signing of this agreement was made at the Octavio Pinto Museum in the city of Villa del Totoral and was made possible by the consensus reached with the medical doctor Silvina Hidalgo, director of the Municipal Hospital of Villa del Totoral, at the time, and today current Secretary of Health, and the Mayor, Mr. Ernesto Bernabey.

They had opened the door to Juan Carlos Vázquez, Dr. Julio Javier Castillo (UTN-FRC) and to us (Institute of GeoHistorical Research/CONICET-National University of the Northeast -IIGHI/CONICET-UNNE). With this, the possibility of listening and listening to us had increased. It was another opportunity to rethink the health, environment, local management, ways of research and social usefulness of research. It also presented the ideal circumstance for developing a proposal covering all fields of social reproduction and nurturing population experience and health and environmental sciences. It was a comprehensive mobilization of the resources of society that was going through not only the efforts of local government, but all the very wide possibilities of environmental health that is carried out within the population organizations themselves with their historical experience.

Thus, in the house of Octavio Pinto, totoralense plastic artist, we met and began to walk a path with Silvina and Ernesto, together with managers and teachers from the three mid-level schools of the city, Ana Colombres and Analía Ocampo, of the Provincial Institute of Agrotechnical Education No. 217, Agronomist José Barrionuevo (IPEA No. 217); Oscar López and Daniel Machado, of the Higher Normal School (ENS) and Viviana Mendoza and Patricia Montero, of the Provincial Institute of Medium and Technical Level No. 74, Fray Mamerto Esquiú (IPETyM No. 74), accompanied by his groups of cohort students from 2012 to the present day, corresponding to 4 th, 5th and 6th year, according to the modality, and by graduates who participated during the development of the research and who are currently tertiary and/or university top-level students.

A stage passed that reaches to this day and involves and challenges us...

Ernesto completed his management in 2014, and remained in office prof. María del Carmen Luján, until 2015. She was succeeded by Mr. José Luis de Lucca, until 2019, and then re-elected until 2023. Prof. Laura Londero (North Technical Inspection, Zone VII under the Directorate General of Technical Education and Vocational Training of the Ministry of Education of the Province of Córdoba), Mr. Pedro Celiz and lawyer Alberto Alaluf, secretaries of government in the management of Ernesto and José Luis, respectively; a doctoral fellow/ National Science and Technology Fund (FONCyT) and three doctoral fellows/CONICET, Rafael Carreras, Santiago Rebollo, Gabriela Gauto and Francisco Berardo.

We jointly initiated transit on the basis of the considerations raised in the previous points on CLRM and IS. We did not take a reasonable position or impose an order in advance, and we held that we are in a better position to find order after we have let ourselves be deployed across the full range of disputes in which we are immersed. The task of defining CLRM and IS is in our hands without discipline and without fit into given categories. This does not mean that the search for order, rigor and patterns is abandoned. Searches are simply highlighted at a higher level of abstraction that allows each actor's own and diverse cosmos to be deployed no more counterintuitively [1].

Hence, we define Villa del Totoral as the area of solidarity celebration marked by the contiguity of the actors and by their processes of interrelationship that build the identity in social ensembles forcing and facilitating those interrelationships. Then, following Milton Santos [38], we say that Villa del Totoral is a human construction, unfinished, in permanent movement and transformation.

This led us to understand the time according to Benjamin, Bloch and Santos, who assign centrality to the present, since actions are given in the present and not in the future [16]. We adopt from Santos the proposal to reverse the dominant logic by expanding the present and reducing the future to create a space-time that accommodates our infinite social experiences without sacrificing our identities [16]. We recover from Santos, from Bloch, the concept of "not yet" in CLRM and IS as an alternative to binary all/nothing thinking that expresses the static of Western thought, that has no meaning or direction and can end in disaster or hope [16]. We work so as not to confuse the idea of time with urgency. We try to stop to think, because acceleration blinds and drags everything, and the urgent displaces the important.

We adhere to Saints [16], who defines the present as an incomplete past and the future as a non-complying present, and proposes a double work on the present: as an incomplete past or as an unfulfilled present.

We agree that the latter has the idea of process involving different actors, objects and interests with interruptions, 
interferences, disorders and displacements typical of a becoming crossed by uncertainties, reason, desire, culture, conflicts and chance. Movements are costly and painful. For this reason, paraphrasing Latour, Deleuze and Guatari [1, 45], it is not possible to start from the idea of objective, since it corresponds to linearity, causality and certainty, typical of simple problems that are devised as angels carrying power and connections in an immaterial way, but it is necessary to fund in the idea of triggering processes striving as ants to generate even the most tiny connection without ignoring the diacritical condition of social play. We emphasize that the process is not intended for non-compliance but to tend to realization. We agree, and take up what has been raised in previous points, with Mario Testa [12], for whom the important thing is to trigger processes. Now, why trigger processes? Well, to become new social actors. And why become new social actors? To install on the state agenda a CLRM and an IS as a territory of the co-construction of knowledge in the field of environmental health.

We recognize ourselves as power and chaos. Power in relation to the idea of acting. On the basis of the act, we can understand our potential. It follows from the power-to-act relationship the passage of less formed entities to more formed entities and showing the dynamic of the relationship $[46,47]$. The will of power regarded as an act of freedom and overcoming [48]. This power was unleashed in a CLRM and IS with a game previously directed that often expressed chaos, unpredictable, which is not synonymous with disorder. We emphasize that chaos reaches scientific status with the development of chaos theory and complex systems, understood as dynamic systems very sensitive to initial variations. Chaos expresses how small variations in initial conditions can mean large differences in future behavior, making prediction impossible. This places CLRM and IS to antipodes in the programming that aims to predict the future.

Hence, it is important to distinguish that discernment of power and chaos is played in the epistemic configuration that comes encoded to each actor by culture (including in it to science). Spinelli [41, p. 163] taking from Magariños de Morentín [48, p. 88]: Man has not in front of himself a world but a mirror of his own semiotic identification systems, so that he does not select what exists in the world but what he perceives in the world.

Thus, understanding power and chaos transcending our epistemic configuration depended on our experience and experimentation.

Gadamer [49] emphasizes the term "experience" to talk about what is learned and lived by the individual and by the group and it is based on common sense. Experience is an objectification of lived life in the form of a thought reality. It is worthwhile highlighting that experience differs from lived life, since it involves the elaboration of the actor upon what he experiments or goes through. On the other hand, the world of experience is the world of life; that is, the basis of all action, as well as of every operation of knowledge and scientific elaboration [50]. Used insistently by Heidegger [51], the concept of experience refers to being-there (just as it unfolds), to the in-the-world being and to human action. The meaning of experience is understanding: the actor "is" understanding himself and his meaning in the world of life. It is from that ontology that he opens himself up to understand others and the world. As a constituent of human existence, according to Heidegger [51], experience does not present itself as a challenge to reflection. On the contrary, reflection receives from the experience its food and movement and is expressed from language in dialogue and the fusion of horizons. The social experience is much broader than that validated by Western scientific and philosophical tradition, even by social science as we know it. In short we try to have more action, less prediction and more dedication which means more action focused on founding and fewer discourses focused on foundation. We adopt Santos' pointing out [16] that we live in a time of strong questions and weak answers, because criticism has been losing the nouns to keep the adjectives by highlighting the crisis of homo academicus [52] that moves to society and expresses that epistemological conflicts are always political conflicts that point to coloniality.

We propose to think along with Latour [1] to glimpse what has been done about CLRM and SI based on a discussion of the ontological, epistemologic and praxiological. This involved, as contextualized in this writing, the conduct of discussions in the classroom of each school, in local, provincial, national and international scientific-technological meetings and in scientific dissemination publications. As complementary issues we highlight, among others, the contribution to the generation of the secretariats of health and environment in Villa del Totoral (management that began in 1994, with the signing of the creation act in the international workshop on CLRM and SI -2015-) and an educational internship agreement between the Ministry of Education of the Province of Córdoba and Municipality of Villa del Totoral in the framework of the scientific-technological transfer maintained by the municipality with CONICET and UTN-FRC. To put it, it is necessary to imagine it, in the words of Latour [1], as a social zoom, con with a camera, a pair of rails, a wheeled vehicle and all the complex work that has to be assembled to realize something as simple as a shooting of a rotating platform. This involved the joint development of assembly and assembly processes between each of us who make up this team and multilateral agencies, inter-American housing networks and healthy habitat; national and provincial science and technology agencies, provincial educational-level agencies, provincial middlelevel and technical schools, national public or private universities and the Americas region; health and environmental management agencies at the local, provincial, national and Region of the Americas levels.

We remain attentive to the following reflection in our journey/walk:

... have you ever noticed in sociology congresses, political meetings or bar conversations, the gestures people make when they invoke the "Great Picture" in which they offer to relocate what you just said so that it "fits" into entities as 
easy to apprehend as "late capitalism," "the rise of civilization," "the West," "modernity," "the history of humanity," "post-colonialism," or "globalization." The gesture of his hands is never greater than what it would be like to caress a pumpkin! Finally, I'm going to show the true size of the "social" in all its greatness: well, it's not that big. It only makes it appear like this with the gesture and professional tone in which it is alluded to the "Great Picture". If there is one thing that is not common sense, it is to consider a medium-sized pumpkin to the equivalent of "the whole society". It's five to midnight for that kind of social theory and the beautiful carriage has been transformed back into what it must always have remained: a member of the Cucurbitaceae family.

I know I'm bad, but sometimes it can be done in a friendly way, like when a surgeon removes a painful wart. Size and zoom should not be confused with the condition of being connected [1, p. 267].

\section{And We Continue to Reflect}

We live in a great contradiction in terms: we are possessed by a will to change the reality of CLRM and SI, now! However, we also feel that the transformations we need are long-term and related to issues of culture and civilization. It's not possible to change everything just now! We think that it is necessary to create and recast CLRM and SI in processes in a way that do not overlook the history of founding practices in the territory. Discrediting programs does not imply discrediting CLRM and SI problems in the territory [41]. Territory is the field of questions if we think actively and act mindfully. That's where come up interrogations like "why?" and "will we ever be able to think, while allowing us the exercise of questioning?" There are no methods and techniques to trigger processes in the territory that would come from social play in dynamics marked by becoming and uncertainty [41]. This is why we bet on dialogue for the development of processes of co-construction of knowledge, where each speech is a reaction to the previous speech and can be understood as an answer and question in a new invitation to speak of it or the actors on a path towards the fusion of horizons.

We do not suggest formulas or recipes and are left with more questions than we asked ourselves when we initiated the writing of this text...

Says Latour [1, p. 245]:

You must travel on foot and keep the decision not to accept any invitation to travel in a faster vehicle. If we should follow the suggestion that interactions are overwhelmed by many established ingredients that come from other times, other spaces and other agents; yes, we must accept the idea of moving to some other sites to find the origins of those numerous ingredients. But as soon as we get out of some interaction, we must ignore the giant signs that point "towards the context" or "towards the structure", we must turn at right angles, leave the roads and opt instead for a tiny path, not much wider than the donkey trail.
To think acting and acting, thinking.

\section{References}

[1] Latour B. Reensamblar lo social. Una introducción a la teoría del actor-red. Buenos Aires: Ediciones Manantial SRL. 2008.

[2] Martínez Salgado C. Abrir la epidemiología. En: Eibenschutz HC, Tamez SG, González RG. ¿Determinación social o determinantes sociales de la salud? México DF: UAM. 2001. $71-90$

[3] Santos BS. Una epistemología del sur. Buenos Aires, Argentina: Siglo XXI Editores, CLACSO. 2013.

[4] Breilh J. Investigación Cualitativa: ¿nuevo fetichismo o endurecimiento de la ciencia? (Otra ciencia es posible). 2020. Available http://repositorio.uasb.edu.ec/bitstream/10644/3381/1/Breilh\% 2C\%20J-CON-082 Investigacion\%20cualitativa.pdf.

[5] Saramago J. Ensaio sobre a Cegueira. Lisboa: Editorial Caminho. 1995.

[6] Santos M. Utopía, Moral Científica e Ambiguedade do Conceito Meio Ambiente. Rio de Janeiro: Seminario Nacional Saude e Meio Ambiente, FIOCRUZ. 2000.

[7] Heidegger M. Qué significa pensar? Madrid: Trotta. 2008.

[8] Bachelard G. Epistemología. Barcelona: Anagrama. 1974.

[9] Castoriadis C. Figuras de lo pensable. Buenos Aires: Fondo de Cultura Económica. 2001.

[10] Rosanvallon P. La nueva cuestión social: Repensar el Estado providencia. Buenos Aires: Ediciones Manantial. 1995.

[11] Piketty T. El capital en el siglo XXI. Bueno Aires: Fondo de Cultura Económica. 2014.

[12] Testa M. Pensar en salud. Buenos Aires: Lugar Editorial. 1993.

[13] Breilh J. Epidemiología Crítica: Ciencia Emancipadora e Interculturalidad. Buenos Aires: Lugar Editorial. 2003.

[14] Freud S. El malestar de la cultura. En: Sigmund Freud: Obras completas. Buenos Aires: Amorrortu Editores. 1978.

[15] Cerdeiras R. La subversión de nuestro siglo. Colección Milenio. 1994.

[16] Santos BS. Una epistemología del sur. Buenos Aires: Siglo XXI Editores, CLACSO. 2013.

[17] Luz M. Natural, racional, social. Buenos Aires: Lugar Editorial. 1997

[18] Horkheimer M, Adorno T. Dialéctica del Iluminismo. Buenos Aires: Sudamericana. 1987.

[19] Jaramillo A. La Universidad frente a los problemas nacionales. Lanús: Ediciones de la UNLa. 2003.

[20] Dussel E. Filosofías del sur: descolonización y transmodernidad. México DF: Akal. 2015.

[21] Freire P. Pedagogía del oprimido. Buenos Aires: Siglo XXI Editores. 2005. 
[22] Varsavsky O. Ciencia, política y cientificismo. Buenos Aires: Centro Editor de América Latina. 1974.

[23] Matus C. Teoría del juego social. Buenos Aires: Ediciones de la UNLa. 2007.

[24] Latour B. Nunca fuimos modernos. Buenos Aires: Siglo XXI Editores. 2007.

[25] Granda E. A qué llamamos salud colectiva, hoy? 2020. Available at: http://scielo.sld.cu/scielo.php?script=sci_arttext\&pid=S086434662004000200009.

[26] Spinelli H. Gestión: prácticas, mitos e ideologías. Buenos Aires: Salud Colectiva. 2017. 13 (4): 577-597.

[27] Mintzberg H. Directivos, no MBA's: Una visión crítica de la dirección de empresas y la formación empresarial. Barcelona: Ediciones DEUSTO Planeta. 2004.

[28] Motta P. La ciencia y el arte de ser dirigente. Bogotá: Ediciones Uniandes. 1993.

[29] Almeida Filho N, Castiel LD, Ayres JRM. Riesgo: concepto básico de la epidemiología. Buenos Aires: Salud Colectiva. 2009. 5 (3): 323-344.

[30] Alazraqui M, Mota E, Spinelli H. Sistemas de Información en Salud: de sistemas cerrados a la ciudadanía social. Un desafío en la reducción de desigualdades en la gestión local. Rio de Janeiro: Cad. Saúde Pública. 2006. 22 (12): 2693-2702.

[31] Moraes IHSD. Informações em saúde: da prática framentada ao exercício da cidadania. São Paulo: Editora Hucitec/Rio de Janeiro: ABRASCO. 1994.

[32] Samaja J. Epistemología de la salud: reproducción social, subjetividad y transdisciplina. Buenos Aires: Lugar Editorial, 2004. $245 \mathrm{p}$.

[33] Spinelli H. (compilador), Salud Colectiva: Cultura; Instituciones; Subjetividad. Epidemiología, Gestión y Políticas. Colección Salud Colectiva. Buenos Aires: Lugar Editorial. 2004.

[34] Flores F. Inventando la Empresa del Siglo XXI. Santiago: Dolmen Ediciones. 1989.

[35] Santos BS. Um discurso sobre as ciências. São Paulo: Cortez. 2003.

[36] Santos M. Território e sociedade. São Paulo: Editora Fundação Perseo Abramo. 2001.
[37] Santos M. A natureza do espaço: Técnica e tempo, razão e emoção. São Paulo: Hucitec Editora. 1997.

[38] Santos M. Por uma geografia nova: Da crítica da geografia a uma geografia crítica. São Paulo: Hucitec Editora. 1996.

[39] Bourdieu P, Wacquant I. Una invitación a la sociología reflexiva. Buenos Aires: Siglo XXI Editores. 2008.

[40] Frei Betto. Martí e a Revolução Cubana. Adital, January 25, 2013 [Retrieved March 12, 2016]. Available a Frei Betto. Martí e a Revolução Cubana. Adital, January 25, 2013 [Retrieved March 12, 2016]. Available at: http://goo.gl/8kmUkd. http://goo.gl/8kmUkd.

[41] Spinelli H. Volver a pensar en salud: programas y territorios. Salud Colectiva. 2016.12 (2): 149-171.

[42] Gadamer HG. A idéia da filosofia prática. En: Gadamer HG. Hermenêutica em retrospectiva III: hermenêutica e a filosofia prática. Petrópolis: Vozes. 2007. p. 27-39.

[43] Ayres JRCM. Para comprender el sentido práctico de las acciones de salud: contribuciones de la Hermenéutica Filosófica. Buenos Aires: Salud Colectiva. 2008. 4 (2): 159-172.

[44] Rojas MC, Meichtry NC, Ciuffolini MB, Vázquez JC, Castillo J. Repensando de manera holística el riesgo de la vivienda urbana precaria para la salud: un análisis desde el enfoque de la vulnerabilidad sociodemográfica. Salud Colectiva. 2008. 4 (2): 187-201.

[45] Deleuze G, Guattari F. Mil mesetas: capitalismo y esquizofrenia. Valencia: Pre-textos. 1988.

[46] Ferrater Mora J. Diccionario de Filosofía. Barcelona: Ariel Filosofía. 1994.

[47] Heidegger M. Nietzsche. Barcelona: Destino. 2000.

[48] Magariños de Morentín JA. el proceso de la significación y su comunicación. En: El mensaje publicitario. Buenos Aires: edicial; 1991. p. 79-113.

[49] Gadamer H. Verdade e método. Petrópolis: Editora Vozes. 1999.

[50] Husserl E. Idéia de fenomenologia. Lisboa: Edições 70. 2001

[51] Heidegger M. Ser e tempo. Petrópolis: Editora Vozes. 1988.

[52] Bourdieu P. Homo Academicus. Buenos Aires: Siglo XXI editores. 2008. 